\title{
Kepatuhan Standar Prosedur Operasional Hand Hygiene pada Perawat di Ruang Rawat Inap Rumah Sakit
}

\section{Adherence to the Standard Operating Procedures on Hand Hygiene of Nurses in Hospital's Inpatient Unit}

\author{
Neila Fauzia ${ }^{1}$, Anis Ansyori', Tuti Hariyanto ${ }^{2}$ \\ ${ }^{1}$ Akademi Kebidanan Pidie Jaya Medan \\ ${ }^{2}$ Program Magister Manajemen Rumah Sakit Fakultas Kedokteran Universitas Brawijaya Malang
}

\begin{abstract}
ABSTRAK
Kesadaran cuci tangan (hand hygiene) pada petugas kesehatan merupakan perilaku yang mendasar dalam upaya mencegah infeksi silang. Cuci tangan mempunyai pengaruh besar terhadap pencegahan terjadinya infeksi nosokomial di rumah sakit dan perawat mempunyai andil besar karena berinteraksi dengan pasien selama 24 jam. Tujuan penelitian ini adalah untuk memperoleh gambaran perilaku cuci tangan perawat di ruang rawat inap rumah sakit X Malang. Penelitian ini merupakan penelitian deskriptif kuantitatif dengan pendekatan cross sectional. Metode yang digunakan dengan cara observasi hanya pada satu kali momen cuci tangan. Subjek penelitian adalah perawat pelaksana yang berada di lima ruang rawat inap. Jumlah sampel yang diambil adalah 43 perawat. Pengumpulan data dengan cara observasi langsung menggunakan tabel cek list berdasarkan Standar Prosedur Operasional (SPO) yang berlaku di rumah sakit X. Hasil penelitian menunjukkan bahwa perilaku hand hygiene perawat sesuai dengan SPO yang berlaku di rumah sakit tersebut secara keseluruhan sebesar 36\% dengan kepatuhan tertinggi pada unit stroke. Tahapan dalam SPO dengan kepatuhan rendah terutama pada detail teknik melakukan cuci tangan.
\end{abstract}

Kata Kunci: Hand hygiene, kepatuhan, perawat, standar prosedur operasional

\begin{abstract}
Awareness of hand hygiene on the health workers is an essential behavior in order to prevent nosocomial infection. Hand hygiene has a major impact on the prevention of nosocomial infections in hospitals and nurses have a big role as they interact with the patient 24 hours a day. The purpose of this study was to obtain an overview of hand washing behavior of nurses in the inpatient units of " $X$ " hospital in Malang. This research is a descriptive quantitative with cross-sectional approach. The method used was by observation only at one moment of hand washing. The subjects were nurses who were in five inpatient units. The number of samples taken was 43 nurses. The data collection was by direct observation using check list tables based on Standard Operating Procedures applicable to hospital $X$. The result showed that hand hygiene behavior of nurses in accordance with the applicable SPO at the hospital was $36 \%$ with the highest adherence in the stroke unit. The stage in the SPO with low adherence is especially on detail techniques of hand-washing.
\end{abstract}

Keywords: Compliance, hand hygiene, nurse, standard operating procedures

Jurnal Kedokteran Brawijaya, Vol. 28, Suplemen No. 1, 2014: Neila Fauzia. Akademi Kebidanan Pidie Jaya, Jl. Raya Banda Aceh Tel. (0653) 51121Email:fauzianayla@ymail.com 


\section{PENDAHULUAN}

Perilaku hand hygiene perawat merupakan salah satu faktor yang mempunyai pengaruh besar terhadap pencegahan terjadinya infeksi nosokomial (INOS) di rumah sakit. Data menunjukkan tingginya angka INOS baik di dunia maupun indonesia. Dari data surveilans World Health Organization (WHO) dinyatakan bahwa angka kejadian INOS sebesar 5\% pertahun (1). Sedangkan di Amerika Serikat angka ini mencapai 6\% (2). Di indonesia INOS di rumah sakit dr. Cipto Mangunkusumo berkisar 0$14,4 \%(3)$.

Dalam buku Standar Pelayanan Minimal Rumah Sakit disebutkan bahwa pencegahan dan pengendalian infeksi nosokomial merupakan pelayanan yang wajib diselenggarakan oleh rumah sakit. Tujuan dari pengendalian INOS adalah untuk melindungi pasien dari infeksi dalam bentuk pencegahan, surveilans, dan pengobatan yang rasional (4). Saat ini angka INOS telah dijadikan salah satu tolok ukur mutu pelayanan rumah sakit. Angka kejadian INOS tidak boleh lebih dari 1,5\% (5). Di negara maju, ijin operasional rumah sakit bisa dicabut karena tingginya angka infeksi nosokomial. Bahkan pihak asuransi tidak mau membayar biaya yang ditimbulkan akibat infeksi nosokomial sehingga pihak penderita sangat dirugikan (2).

Infeksi nosokomial terjadi karena transmisi mikroba patogen. Secara umum sumber atau penyebab INOS dikelompokkan berdasarkan: 1) faktor lingkungan yang meliputi udara, air, dan bangunan, 2) faktor pasien yang meliputi umur, keparahan penyakit, dan status kekebalan, 3) faktor atrogenik yang meliputi tindakan operasi, tindakan invasif, peralatan dan penggunaan antibiotik (6). Selain faktor penyebab terdapat juga faktor predisposisi INOS. Faktor predisposisi tersebut yaitu: 1) faktor keperawatan seperti lamanya dirawat, menurunnya standar pelayanan perawat serta padatnya penderita dalam satu ruang; 2) faktor mikroba patogen seperti tingkat kemampuan merusak jaringan, lamanya pemaparan antara sumber penularan dengan penderita (7).

Pencegahan dan pengendalian infeksi nosokomial diartikan sebagai upaya mencegah dan mengendalikan infeksi dengan cara menghambat pertumbuhan transmisi mikroba yang berasal dari sumber di sekitar penderita yang sedang dirawat. Upaya tersebut dilakukan dengan menerapkan kewaspadaan standar. Kewaspadaan standar harus mampu melindungi dan petugas kesehatan dari infeksi.

Pada bebarapa penelitian dikatakan bahwa hand hygiene bisa menurunkan kejadian infeksi nosokomial. Di beberapa negara berkembang kejadian INOS menurun seiring dengan meningkatnya kesadaran akan hand hygiene (8). Beberapa study juga menunjukkan adanya hubungan antara hand hygiene dengan berkurangnya infeksi. Pada penelitian meta analisis dari beberapa penelitian disimpulkan bahwa hand hygiene mampu menurunkan angka INOS (9).

Mencuci tangan selama pelaksanaan tindakan keperawatan merupakan cara yang paling efektif untuk mencegah terjadinya infeksi nosokomial di lingkungan rumah sakit. Tenaga kesehatan yang paling rentan dalam penularan infeksi adalah perawat karena selama 24 jam mendampingi pasien, maka diasumsikan ikut mengambil peran yang cukup besar dalam memberikan kontribusi terhadap pencegahan infeksi nosokomial (10).

Hasil studi pendahuluan di rumah sakit X Malang, didapatkan data sekunder dari tim Panitia Pengendalian Infeksi Rumah Sakit (PPIRS) angka infeksi nosokomial di ruang rawat inap masih diatas standar yaitu $2,58 \%$. Hasil wawancara dengan tim PPIRS menyatakan bahwa masih banyak perawat yang belum melakukan cuci tangan sesuai dengan SPO serta hasil observasi awal diperoleh data bahwa dari 10 orang perawat ruangan, terdapat 7 orang perawat dalam melakukan tindakan keperawatan tidak mencuci tangan dan tidak mengikuti prosedur langkah mencuci tangan yang telah ditetapkan oleh rumah sakit. Berdasarkan uraian di atas, maka perlu dilakukan penelitian mengenai gambaran cuci tangan perawat selama pelaksanaan tindakan keperawatan di rumah sakit $X$.

\section{METODE}

Rancangan penelitian yang digunakan adalah penelitian deskriptif kuantitatif. Populasi penelitian ini adalah seluruh perawat yang bekerja di ruang rawat inap rumah sakit X Malang. Sampel yang diambil sebanyak 43 responden dari 5 ruang percontohan rawat inap di rumah sakit $\mathrm{X}$ dengan menggunakan teknik simple random sampling yaitu ruang ICU, PICU NICU, Kamar Bersalin, Unit Stoke dan Teratai. Penelitian ini menggunakan daftar tilik dengan metode observasi langsung untuk menilai perilaku perawat dalam melaksanakan hand hygiene berdasarkan Standar Prosedur Operasionl (SPO) yang berlaku. Observasi yang dilakukan hanya sekali dan hanya pada satu momen cuci tangan. Setiap perawat yang menjadi responden diminta untuk melakukan cuci tangan sesuai dengan SPO yang berlaku di rumah sakit X. Dari daftar tilik perilaku cuci tangan perawat diberi bobot berdasarkan skala Likert. Jika perawat melakukan setiap langkah cuci tangan dengan baik dan benar sesuai dengan tahapan SPO maka diberi nilai 3, jika melakukan tetapi tidak benar seperti langkah yang ada di SPO diberi nilai 2 dan jika tidak melakukan sama sekali tahapan cuci tangan sesuai dengan SPO diberi nilai 1 . Selanjutnya dilakukan analisa deskriptif sikap perawat dalam melakukan hand hygiene didasarkan pada kumulatif nilai rerata yang didapat responden dan dikelompokkan kedalam kategori interval baik (rerata 4045), cukup (rerata 30-39), kurang (rerata 15-29). Untuk melihat secara keseluruhan sikap responden terhadap hand hygiene didasarkan pada nilai rerata yang didapat responden secara bersama.

\section{HASIL}

Berdasarkan hasil observasi pada 43 responden dari lima ruang rawat inap didapatkan perilaku hand hygiene perawat sesuai dengan SPO yang berlaku di rumah sakit tersebut secara keseluruhan sebesar 36\% (Tabel 1). Kepatuhan tertinggi ditemukan pada ruang Stroke. Kepatuhan pada ruang intensif tidak menunjukkan gambaran yang berbeda dengan ruang perawatan umum. 
Tabel 1. Perilaku hand hygiene perawat sesuai SPO menurut ruang rawat inap

\begin{tabular}{lc}
\hline \multicolumn{1}{c}{ Ruang } & Perilaku Hand Hygiene \\
\hline PICU NICU & $30 \%$ \\
Kamar Bersalin & $35 \%$ \\
Unit Stroke & $50 \%$ \\
Teratai & $36 \%$ \\
ICU & $29 \%$ \\
RERATA & $36 \%$ \\
\hline
\end{tabular}

Berdasarkan Tabel cek list SPO hand hygiene, diperoleh persentase untuk setiap tahapan pelaksanaan hand hygiene (Tabel2). Hasil menunjukkan bahwa kepatuhan tertinggi (62\%-65\%) adalah pada komponen SPO perilaku yang sama dengan prosedur sebelumnya (prosedur ke 47). Komponen yang lain menunjukkan kepatuhan yang rendah karena bersifat baru dan lebih detail.

Tabel 2. Persentase tahapan pelaksanaan hand hygiene sesuai dengan SPO yang berlaku

\begin{tabular}{|c|c|c|}
\hline No & $\begin{array}{c}\text { Tahapan Hand Hygiene sesuai dengan } \\
\text { SPO }\end{array}$ & Pelaksanaan \\
\hline 1 & Melepas semua aksesoris & $37 \%$ \\
\hline 2 & $\begin{array}{l}\text { Melakukan inspeksi tangan dan jari (kuku } \\
\text { dan adanya luka) }\end{array}$ & $37 \%$ \\
\hline 3 & $\begin{array}{l}\text { Menjaga agar tangan dan pakaian tidak } \\
\text { menyentuh wastafel }\end{array}$ & $36 \%$ \\
\hline 4 & Mengalirkan air & $65 \%$ \\
\hline 5 & Membasuh tangan dan lengan bawah & $61 \%$ \\
\hline 6 & Menaruh sedikit sabun/antiseptik (2-4 cc) & $61 \%$ \\
\hline 7 & $\begin{array}{l}\text { Menggosok punggung tangan, sela-sel } \\
\text { ajari }\end{array}$ & $62 \%$ \\
\hline 8 & $\begin{array}{l}\text { Menggosok sela-sela jari secara melingkar } \\
\text { minimal } 5 \text { kali }\end{array}$ & $38 \%$ \\
\hline 9 & $\begin{array}{l}\text { Menggosok punggung jari tangan } \\
\text { ketelapak tangan lain }\end{array}$ & $39 \%$ \\
\hline 10 & Menggosok ibu jari secara melingkar & $37 \%$ \\
\hline 11 & $\begin{array}{l}\text { Menggosok kuku dan ujung jari ketelapak } \\
\text { tangan lain }\end{array}$ & $35 \%$ \\
\hline 12 & Membilas tangan sampai bersih & $42 \%$ \\
\hline 13 & Menutup krans dengan siku & $36 \%$ \\
\hline 14 & $\begin{array}{l}\text { Mengeringkan tangan dengan handuk atau } \\
\text { pengering }\end{array}$ & $36 \%$ \\
\hline
\end{tabular}

\section{DISKUSI}

Hasil evaluasi pelaksanaan hand hygienedi rumah sakit $\mathrm{X}$ didapatkan secara keseluruhan perilaku perawat berada pada kategori cukup yaitu $36 \%$ yang melaksanakan hand hygiene sesuai dengan SPO. Hasil ini sesuai dengan penelitian yang dilakukan oleh Pittet (9) yang menunjukkan tingkat kepatuhan petugas kesehatan dalam melakukan hand hygiene masih kurang dari 50\%. Beberapa penelitian melaporkan bahwa kepatuhan cuci tangan masih rendah. Menurut WHO kepatuhan cuci tangan harus lebih dari $50 \%$.

Hasil observasi dari lima ruang rawat inap, ICU menjadi ruangan dengan perilaku hand hygiene terendah diantara ruangan yang lain yaitu $28 \%$ perawat yang melakukan hand hygiene sesuai dengan SPO yang berlaku. Hal ini menunjukkan pasien di unit perawatan intensif berisiko terkena infeksi nosokomial lebih tinggi dibandingkan ruang lain di rumah sakit. Hasil ini sesuai dengan penelitian yang dilakukan di 18 rumah sakit di Swiss menyebutkan bahwa prevalensi infeksi nosokomial sebesar 10,1 \% dengan kejadian terbanyak pada ruang ICU sebesar 29,7\%

Berdasarkan hasil observasi dengan menggunakan cek list SPO, hampir semua palaksanaan langkah cuci tangan berdasarkan SPO rata-rata masih tergolong rendah yaitu berkisar dari 36\%-42\%. Hal ini sesuai dengan teori yang menyatakan bahwa banyak petugas kesehatan yang tidak taat dengan prosedur cuci tangan, dengan berbagai alasan diantaranya infrastruktur dan peralatan cuci tangan letaknya kurang strategis, terlalu sibuk, tangan tidak terlihat kotor, sudah menggunakan sarung tangan, kulitnya bisa mengalami iritasi bila terlalu sering cuci tangan, dan cuci tangan menghabiskan banyak waktu (10). Mencuci tangan selama pelaksanaan tindakan keperawatan merupakan cara yang paling efektif untuk mencegah terjadinya infeksi nosokomial di lingkungan rumah sakit. Tenaga kesehatan yang paling rentan dalam penularan infeksi adalah perawat karena 24 jam mendampingi pasien, sehingga mengambil peran yang cukup besar dalam memberikan kontribusi terhadap pencegahan infeksi nosokomial (13).

Cuci tangan harus dilakukan dengan benar sebelum dan sesudah melakukan tindakan perawatan meskipun memakai sarung tangan atau alat pelindung lain untuk menghilangkan atau mengurangi mikroorganisme yang ada di tangan sehingga penyebaran penyakit dapat dikurangi dan lingkungan terjaga dari infeksi. Indikasi cuci tangan harus dilakukan pada saat yang diantisipasi akan terjadi perpindahan kuman melalui tangan, yaitu sebelum melakukan tindakan yang dimungkinkan terjadi pencemaran dan setelah melakukan tindakan yang dimungkinkan terjadi pencemaran (5). Mencuci tangan merupakan teknik dasar yang paling penting dalam pencegahan dan pengontrolan infeksi (14).

Dalam sebuah penelitian, faktor-faktor yang mempengaruhi perilaku petugas kesehatan terhadap kepatuhan mencuci tangan yaitu faktor individu, organisasi dan lingkungan (9). Ketiga faktor tersebut mempunyai ketergantungan dalam mempengaruhi kepatuhan dalam melaksanakan hand hygiene. Faktor individu yang mempengaruhi yaitu pengetahuan, sikap, beban kerja, dan motivasi. Faktor organisasi meliputi ada tidaknya prosedur tetap, sanksi, penghargaan, dukungan, pelatihan dan ketersediaan fasilitas sarana dan prasarana yang menunjang pelaksanaan hand hygiene. Faktor lingkungan meliputi air dan arsitektur bangunan.

Penerapan cuci tangan pada perawat juga harus didukung oleh kesadaran perawat itu sendiri dalam melindungi diri dan pasien dari bahan infeksius serta kesadaran dalam menjalankan SOP yang benar. Kebiasaan mencuci tangan perawat di rumah sakit, merupakan perilaku mendasar dalam upaya pencegahan cross infection (infeksi silang). Pengetahuan merupakan elemen yang sangat penting untuk terbentuknya tindakan seseorang. Perawat juga harus memiliki pengetahuan tentang cuci tangan dengan benar sebagai upaya pencegahan infeksi nosokomial di rumah sakit sehingga dapat meningkatkan kualitas pelayanan. 
Salah satu langkah dari pihak rumah sakit untuk meningkatkan pengetahuan perawat adalah dengan mengadakan pelatihan atau sosialisasi secara periodik terhadap pelaksanaan hand hygiene. Karena pelatihan dan sosialisasi dapat memberikan dampak yang positif terhadap sikap perawat dalam melakukan hand hygiene. $\mathrm{Hal}$ ini sesuai dengan teori yang menjelaskan bahwa pelatihan merupakan upaya untuk melakukan perubahan perilaku afektif yang meliputi perubahan sikap seorang terhadap sesuatu (15). Pendapat lain menyatakan bahwa pelatihan dapat memberikan informasi kepada perawat

\section{DAFTAR PUSTAKA}

1. Roeshadi D dan Winarti A. Pengendalian Infeksi Nosokomial di RSUD dr. Soetomo Surabaya. Cermin Kedokteran Indonesia. 1993; 82: 13-15.

2. Hasbullah HT. Pengendalian Infeksi Nosokomial di RS Persahabatan Jakarta. Cermin Kedokteran Indonesia. 1993; 82: 8-12.

3. Utji R. Pengendalian Infeksi Nosokomial di RS dr. Cipto Mangunkusumo dengan Sumber Daya Minimal. Cermin Kedokteran Indonesia. 1993; 82: 5-7.

4. Wijono D. Manajemen Mutu Pelayanan Kesehatan, Teori, Strategi, dan Aplikasi. Surabaya: Airlangga University Press; 2000.

5. Departemen Kesehatan Republik Indonesia. Pedoman Manajerial Pencegahan dan Pengendalian Infeksi di Rumah Sakit dan Fasilitas Pelayanan Kesehatan Lainnya. Jakarta: Departemen Kesehatan $\mathrm{Rl} ; 2008$.

6. Weinstein RA. Nosocomial Infection Update County Hospital and Rus Medical College. USA: Chicago Illinois; 1998.

7. Darmadi. Infeksi Nosokomial Problematika dan Pengendaliannya. Jakarta: Salemba Medika; 2008.

8. Duerink DO, Farida H, Nagelkerke NJ, et al. Preventing Nosocomial Infection: Improving Compliance with untuk membentuk sikap positif dan meningkatkan ketrampilan dalam melaksanakan tugas-tugasnya (10).

Hasil penelitian ini diharapkan dapat menjadi masukan bagi rumah sakit dalam menerapkan prosedur hand hygiene untuk mencegah terjadinya infeksi nosokomial dalam upaya meningkatkan mutu pelayanan keperawatan dan menurunkan resiko kejadian infeksi nosokomial. Kepatuhan hand hygiene diharapkan dapat memperpendek hari perawatan dan biaya perawatan di rumah sakit.

Standar Precautions in an Indonesia Teaching Hospital. Journal of Hospital Infection. 2006; 64(1): 3643.

9. Pittet D. Improving Adherence to Hand Hygiene Practice: A Multidisiplinary Approach. Emerging Infectious Desease. 2001; 7(2): 234-240.

10. Tietjen L. Panduan Pencegahan Infeksi untuk Fasilitas Pelayanan Kesehatan dengan Sumber Daya Terbatas. Jakarta: YBP Sarwono Prawiroharjo; 2005.

11. Allegranzi B and Pittet D. Role of Hand Hygiene in Healthcare-Associated Infection Prevention. Journal of Hospital Infection. 2009; 73(4): 305-315.

12. Vincent JL. Nosocomial Infection in Adult Intensive Care Unit. The Lancet. 2003; 361(9374): 2068-2077.

13. Idayanti. Hubungan Pengetahuan dan Sikap Perawat Terhadap Penerapan Standar Operasional Prosedur (SOP) Teknik Menyuntik dalam Upaya Pencegahan Infeksi di RSUD Arifin Achmad Pekanbaru. [Skripsi]. Universitas Sumatera Utara, Medan. 2008.

14. Potter dan Perry. Buku Ajar Fundamental Keperawatan: Konsep, Proses, dan Praktik. Edisi 4. Jakarta: EGC; 2005.

15. Ginting M. Infeksi Nosokomial dan Manfaat Pelatihan Ketrampilan Perawat terhadap Pengendaliannya di RSU H. Adam Malik. Jurnal Ilmiah Pannmed. 2006; 1(1). 